\author{
Г. М. Кривенко, Л. В. Возняк, В. О. Зорін \\ Івано-Франківський національний технічний \\ університет нафти і газу
}

\title{
АНАЛІЗ ВИКИДІВ ЗАБРУДНЮВАЛЬНИХ РЕЧОВИН В АТМОСФЕРНЕ ПОВІТРЯ СТАЦІОНАРНИМИ ДЖЕРЕЛАМИ
}

Для оцінювання викидів шкідливих речовин в атмосферне повітря було взято ІваноФранківську область, оскільки ця область налічує немалу кількість рекреаційних ресурсів.

Відходи виробництва електроенергії на теплоелектростанціях ускладнюють екологічну ситуацію в країні. Вирішення проблем, що пов'язані з охороною навколишнього середовища та покращення якості його соціальної складової, завжди є актуальним. Актуальність полягає у зменшенні техногенного навантаження на довкілля підприємствами, що генерують тепло.

Метою роботи $\epsilon$ аналізування i прогнозування викидів забруднювальних речовин в атмосферне повітря стаціонарними джерелами. У процесі досліджень вирішено питання аналізу приземних концентрацій забруднювальних речовин на межі санітарно-захисної зони та прогнозної оцінки подальших викидів.

Проаналізовано зміну викидів забруднювальних речовин за певний період часу. Для аналізу існуючих викидів Бурштинської ТЕС та їхнього порівняння з ГДК розраховано приземні концентрації забруднювальних речовин на межі санітарно-захисної зони. Бурштинська ТЕС належить до другої категорії небезпеки. Побудовано прогнозну оцінку подальших викидів та наведено заходи щодо їхнього мінімізування. Розраховано індекс токсичності з урахуванням вагових коефіцієнтів. Аналіз викидів свідчить про перевищення ГДК для деяких забруднювальних речовин. За індексом токсичності, який враховує як клас небезпеки речовини, так і ступінь перевищення ГДК, рекомендовано заходи щодо зменшення викидів певних речовин та вибору палива з меншим їхнім вмістом.

Рекомендовано вибір палива 3 меншим вмістом у викидах не тільки таких речовин як оксид азоту, речовини у вигляді суспендованих твердих частинок, діоксиду сірки, але і свинцю та його сполук. При встановленні та реконструкції систем очищення димових газів для Бурштинської ТЕС необхідно враховувати фільтрувальну здатність обладнання щодо речовин 3 великим значенням індексу токсичності.

Для уніфікації розрахунків, аналізу в розрізі обраного періоду часу, можливості застосування для інших об'єктів господарювання було розроблено програмне забезпечення.

Ключові слова: прогнозна оцінка, діоксид сірки, оксид азоту, концентрація, індекс токсичності.

Постановка проблеми. Аналіз досліджень і публікацій. На сьогодні у світі поставлено ряд важливих питань, що стосуються раціонального використання та виробництва енергетичних ресурсів. Найпопулярнішим трендом стало використання енергії, отриманої від природних сил, таких як сонячна та вітрова енергії. Але не завжди ці методи покриття енергетичних потреб $\mathrm{\epsilon}$ доцільними, достатніми і рентабельними. Тому поки що існують такі види генерування енергії як атомні, теплові та гідроелектростанції. Які, в свою чергу, створюють ряд екологічних проблем, що загрожують як навколишньому середовищу, так і існуванню людства загалом.

Відходи виробництва електроенергії на теплоелектростанціях ускладнюють екологічну ситуацію в країні.

Вирішення проблем, пов’язаних із охороною навколишнього середовища та покращенням якості його соціальної складової, завжди $є$ актуальним. Актуальність полягає у зменшенні техногенного навантаження на довкілля підприємствами, що генерують тепло.

Проблемі дослідження викидів забруднювальних речовин в атмосферне повітря присвячено багато наукових робіт, а саме: Адаменка О. М., Семчука Я. М., Крижанівського Є. І., Мєднікова Є. П., Адаменка Я. О., Говдяка Р. М., Кошлак Г. В., Консевич Л. М., Клименка М. О., Панківського Ю. І., Залеського І. І., Білецької Г. А. та інших [1-3, 5-8, 10-11]. 3 аналізу літературних джерел, присвячених проблемам викидів забруднювальних речовин, випливає, що існує необхідність комплексного аналізу викидів, що дасть змогу їх спрогнозувати та вжити ефективних заходів щодо мінімізування забруднення довкілля. 
Мета досліджень. Метою роботи $є$ аналіз і прогнозування викидів забруднювальних речовин в атмосферне повітря стаціонарними джерелами.

У процесі досліджень вирішено такі завдання:

- аналізування приземних концентрацій забруднювальних речовин на межі санітарнозахисної зони;

- прогнозне оцінювання подальших викидів та рекомендація використання заходів щодо їхнього мінімізування.

Матеріали та методи досліджень. Для оцінювання викидів шкідливих речовин у атмосферне повітря було взято Івано-Франківську область, оскільки ця область налічує немалу кількість рекреаційних ресурсів. Згідно зі статистичними даними, 2017 року в атмосферне повітря області потрапило 198,3 тис. тонн забруднювальних речовин. Це на 0,8\% більше, ніж у 2016 році [15]. Статистичні дані щодо викидів забруднювальних речовин в атмосферне повітря стаціонарними джерелами забруднення підприємств за містами Івано-Франківської області у 2017 році та порівняння з 2016 роком наведено у таблиці 1 [15].

Викиди забруднювальних речовин в атмосферне повітря за містами Івано-

Таблиия 1 Франківської області у 2017 році

\begin{tabular}{|l|c|c|c|c|c|c|}
\hline \multirow{2}{*}{ Населений пункт } & \multirow{2}{*}{$\begin{array}{c}\text { Обсяги } \\
\text { викидів, }\end{array}$} & \multirow{2}{*}{$\begin{array}{c}\text { \% до } \\
\text { тонн }\end{array}$} & $2016 \mathrm{p}$. & \multicolumn{4}{|c|}{ У тому числі } \\
\cline { 4 - 7 } & & & тонн & \% до 2016 p. & тонн & \% до 2016 p. \\
\hline Область & 198324,7 & 100,8 & 129606,2 & 94,1 & 14497,8 & 108,7 \\
\hline м. Івано-Франківськ & 447,2 & 99,9 & 7,2 & 113,5 & 58,4 & 122,5 \\
\hline м. Болехів & 199,4 & 103,4 & 0,2 & 100,0 & 6,4 & 194,1 \\
\hline м. Бурштин & 160137,9 & 95,0 & 113795,0 & 89,5 & 11121,4 & 103,5 \\
\hline м. Калуш & 20048,7 & 156,6 & 15560,0 & 150,7 & 948,2 & 267,0 \\
\hline м. Коломия & 143,7 & 98,9 & 9,5 & 97,5 & 18,9 & 110,9 \\
\hline м. Яремче & 100,8 & 100,1 & 25,0 & 98,4 & 2,9 & 51,5 \\
\hline
\end{tabular}

Як видно 3 табл. 1, найбільшим забруднювачем у Івано-Франківській області $є$ місто Бурштин, а, оскільки, зі слів міністра екології та природних ресурсів Остапа Семерака, до першої трійки найбільших забруднювачів атмосферного повітря в Україні у 2016 році входила Бурштинська ТЕС, частка забруднення від якої у 2016 році становила приблизно 85,7\% загальнообласних викидів (2017 рік - 80,7\%), то надалі в цій роботі саме Бурштинська ТЕС розглядатиметься як основний забруднювач області.

За даними Івано-Франківського центру статистики Бурштинська ТЕС має таку динаміку викидів станом з 2011 до 2016 року (табл. 2 [15]).

Україна є членом Енергетичного співтовариства, а отже, зобов'язана дотримуватися умов Договору про створення Енергетичного співтовариства і відповідно його додатків. Згідно 3 Додатком II до Договору всі установки для спалювання палива мають відповідати вимогам Директиви 2001/80/ЕС про обмеження викидів деяких забруднювальних речовин у повітря від них. Директива 2010/75/EU про промислові викиди, що була прийнята на зміну Директиви 2001/80/EC, внесла значні зміни до чинного законодавства ЄС стосовно установок для спалювання палива. Одна з найважливіших змін полягає в більш жорстких граничних значеннях викидів для діоксиду сірки (далі $-\mathrm{SO}_{2}$ ), оксидів азоту (далі - $\mathrm{NO}_{x}$ ) та речовин у вигляді суспендованих твердих частинок, недиференційованих за складом, (далі - пил).

Через недотримання вимог українського екологічного законодавства переважна більшість установок для спалювання палива має бути виведена з експлуатації, що призведе до зменшення наявних потужностей у національній енергетичній системі та зниження виробництва електричної і теплової енергії. Можливість для України тимчасового відступу від вимог Директиви 2001/80/СС (згідно зі статтею 4) шляхом впровадження Національного плану скорочення викидів має суттєве значення для енергетичної безпеки держави (табл. 3 [14]).

Після завершення терміну дії Національного плану скорочення викидів всі установки для спалювання палива мають відповідати вимогам Директиви 2010/75/ЄС щодо викидів перелічених вище забруднювальних речовин. 
Таблиия 2

Динаміка викидів забруднювальних речовин в атмосферне повітря Бурштинською TEC (2011-2016 p.p.)

\begin{tabular}{|c|c|c|c|c|c|c|}
\hline \multirow{2}{*}{ Назва речовини } & \multicolumn{6}{|c|}{ Динаміка викидів забруднювальних речовин в атмосферне повітря, тонн/рік } \\
\hline & 2011 & 2012 & 2013 & 2014 & 2015 & 2016 \\
\hline $\begin{array}{l}\text { Арсен та його } \\
\text { сполук }\end{array}$ & 4,301 & 4,255 & 4,513 & 4,645 & 5,052 & 4,788 \\
\hline $\begin{array}{l}\text { Ванадій та його } \\
\text { сполуки }\end{array}$ & 0,016 & 0,074 & 0,027 & 0,013 & 0,922 & 0,018 \\
\hline $\begin{array}{l}\text { Залізо та його } \\
\text { сполуки }\end{array}$ & 0,277 & 0,222 & 0,217 & 0,021 & 0,024 & 0,145 \\
\hline $\begin{array}{l}\text { Мідь та їі } \\
\text { сполуки }\end{array}$ & 3,419 & 3,365 & 3,528 & 3,631 & 3,987 & 3,798 \\
\hline $\begin{array}{l}\text { Нікель та його } \\
\text { сполуки }\end{array}$ & 3,863 & 3,523 & 4,025 & 4,144 & 4,504 & 4,330 \\
\hline $\begin{array}{l}\text { Ртуть та ӥї } \\
\text { сполуки }\end{array}$ & 0,361 & 0,729 & 0,391 & 0,461 & 0,455 & 0,410 \\
\hline $\begin{array}{l}\text { Свинець та його } \\
\text { сполуки }\end{array}$ & 3,567 & 3,654 & 3,715 & 4,373 & 4,800 & 4,564 \\
\hline $\begin{array}{l}\text { Хром та його } \\
\text { сполуки }\end{array}$ & 4,881 & 4,805 & 5,048 & 5,255 & 5,934 & 5,591 \\
\hline $\begin{array}{l}\text { Цинк та його } \\
\text { сполуки }\end{array}$ & 11,887 & 11,767 & 12,383 & 12,752 & 13,992 & 13,317 \\
\hline $\begin{array}{l}\text { Манган та його } \\
\text { сполуки }\end{array}$ & 0,023 & 0,016 & 0,019 & 0,006 & 0,002 & 0,050 \\
\hline $\begin{array}{l}\text { Речовини у } \\
\text { вигляді } \\
\text { суспендованих } \\
\text { твердих } \\
\text { частинок }\end{array}$ & 23183,402 & 21513,739 & 22234,425 & 25283,982 & 30344,789 & 27960,271 \\
\hline Діоксид азоту & 11354,319 & 12812,872 & 13148,793 & 13082,255 & 12372,540 & 10749,752 \\
\hline Оксид азоту & 128,984 & 140,616 & 146,413 & 146,978 & 144,760 & 124,818 \\
\hline Діоксид сірки & 162642,848 & 138697,194 & 145698,662 & 159928,632 & 152169,450 & 127097,611 \\
\hline Оксид вуглецю & 1087,149 & 1193,384 & 1208,417 & 1225,098 & 1181,981 & 979,835 \\
\hline Ксилол & 1,777 & 1,499 & 1,381 & 0,696 & 0,600 & 0,381 \\
\hline $\begin{array}{l}\text { Крім того } \\
\text { діоксид вуглецю }\end{array}$ & 8537995,65 & 9186830,18 & 9260703,337 & 9549579,509 & 9392522,996 & 8440207,669 \\
\hline
\end{tabular}

Статистичну обробку даних, наведених у табл. 1-3, проводили, використовуючи пакет програм Microsoft Office Excel.

Виклад основного матеріалу. За результатами табл. 1-3 побудовано прогнозну оцінку подальших викидів забруднювальних речовин без урахування заходів щодо встановлення та реконструкції систем очищення димових газів для Бурштинської ТЕС. Результати наведені на рисунках 1-3.

Для опису динаміки викиду діоксиду сірки, оксидів азоту та пилу побудовані лінії тренду засобами MS Excel на основі точкової діаграми за фактичними даними. При побудові лінії тренду вибрано лінійну апроксимуючу криву, оскільки скорочення обсягів викидів згідно з Національним планом також має лінійну залежність. Це дасть змогу спростити порівняльний аналіз.

Як видно з рисунків 1-3, необхідно застосовувати комплексні заходи для зниження рівня викидів, що планується здійснити за допомогою:

- будівництва нових енергоблоків (27 нових блоків ТЕС і ТЕЦ);

- обмеженої кількості годин роботи енергоблоків з подальшим їхнім виведенням із експлуатації (133 установок);

- оснащення існуючих блоків газоочисними спорудами (90 установок) [12].

Для аналізу існуючих викидів Бурштинської ТЕС та їхнього порівняння з ГДК розраховано приземні концентрації забруднювальних речовин на межі санітарно-захисної зони згідно 3 методикою, викладеною у нормативному документі ОНД-86. 
Бурштинська ТЕС належить до другої категорії небезпеки із нормативною шириною санітарно-захисної зони 500 м $[4,11]$.

Таблиия 3

Національний план скорочення викидів

\begin{tabular}{|c|c|c|c|c|c|c|c|c|c|c|c|c|c|c|c|c|}
\hline $\begin{array}{c}\text { Назва } \\
\text { установки }\end{array}$ & 2018 & 2019 & 2020 & 2021 & 2022 & 2023 & 2024 & 2025 & 2026 & 2027 & 2028 & 2029 & 2030 & 2031 & 2032 & 2033 \\
\hline \multicolumn{17}{|c|}{ Вимоги до щорічного скорочення у період 2018-2033 років обсягів викидів діоксиду сірки (т/рік) } \\
\hline $\begin{array}{l}\text { Бурштинська } \\
\text { ТЕС } \\
\text { (енергоблоки } \\
9,10,11,12) \\
\end{array}$ & $\begin{array}{l}a \\
i n \\
n \\
n\end{array}$ & $\begin{array}{l}\stackrel{4}{2} \\
\text { İ } \\
n\end{array}$ & $\begin{array}{l}\overrightarrow{8} \\
\stackrel{n}{8} \\
\dot{y}\end{array}$ & 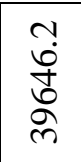 & $\begin{array}{r}\stackrel{m}{*} \\
\stackrel{m}{m}\end{array}$ & 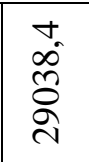 & $\begin{array}{l}0 \\
\dot{D} \\
\hat{n} \\
\end{array}$ & $\begin{array}{l}\tilde{\delta} \\
\tilde{\infty} \\
\infty\end{array}$ & $\begin{array}{l}\infty \\
6 \\
\stackrel{0}{1} \\
=\end{array}$ & 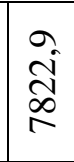 & $\frac{a}{n}$ & - & - & - & - & - \\
\hline \begin{tabular}{|l|} 
Бурштинська \\
TЕС \\
(енергоблоки 8)
\end{tabular} & $\begin{array}{l}\bar{b} \\
\dot{0} \\
\dot{0}\end{array}$ & $\begin{array}{l}n \\
\tilde{n} \\
n \\
\infty\end{array}$ & $\begin{array}{l}2 \\
\infty \\
\infty \\
2 \\
2\end{array}$ & $\begin{array}{l}n \\
\frac{n}{6} \\
6\end{array}$ & $\underset{\substack{+\infty \\
\infty}}{\substack{n \\
.}}$ & $\begin{array}{l}n \\
0 \\
0 \\
a \\
a \\
\end{array}$ & $\begin{array}{l}0 \\
\text { in } \\
\infty \\
0 \\
\dot{y}\end{array}$ & $\begin{array}{l}0 \\
\infty \\
\infty \\
\infty\end{array}$ & సิ & $\begin{array}{l}\infty \\
\dot{8} \\
\dot{0} \\
\end{array}$ & $\hat{\theta}$ & & - & - & - & \\
\hline Разом & 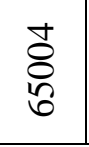 & $\begin{array}{l}\text { ch } \\
\vdots \\
\infty \\
\infty \\
n \\
n\end{array}$ & $\begin{array}{l}+ \\
\infty \\
\infty \\
0 \\
\text { N } \\
\text { n }\end{array}$ & \begin{tabular}{l}
$n$ \\
0 \\
\multirow{z}{*}{} \\
+
\end{tabular} & $\begin{array}{l}\hat{i} \\
\text { à } \\
\vdots \\
+\end{array}$ & 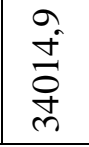 & $\begin{array}{l}\frac{N}{N} \\
\frac{\infty}{2} \\
\end{array}$ & $\frac{a}{\frac{a}{2}}$ & $\stackrel{n}{\stackrel{n}{*}}$ & ลิ & ڤે & - & - & - & - & \\
\hline \multicolumn{17}{|c|}{ Вимоги до щорічного скорочення у період 2018-2033 років обсягів викидів оксидів азоту (т/рік) } \\
\hline $\begin{array}{l}\text { Бурштинська } \\
\text { TЕС } \\
\text { (енергоблоки } \\
9,10,11,12) \\
\end{array}$ & $\begin{array}{l}\text { nิ } \\
\text { ลิ }\end{array}$ & $\begin{array}{l}n \\
\frac{n}{n}\end{array}$ & $\frac{\tilde{a}}{\hat{a}}$ & 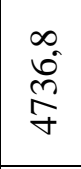 & $\begin{array}{l}\tilde{n} \\
\stackrel{\gamma}{\gamma}\end{array}$ & 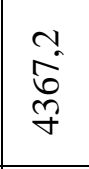 & 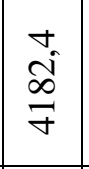 & $\begin{array}{l}0 \\
\frac{0}{2} \\
\text { ले }\end{array}$ & $\frac{\hat{N}}{\infty}$ & సે & $\overrightarrow{⿱ 乛 ⿻}$ & $\begin{array}{l}m \\
\infty \\
n \\
\tilde{n}\end{array}$ & $\stackrel{n}{\tilde{n}}$ & $\begin{array}{l}0 \\
\infty \\
\infty \\
\infty \\
\infty\end{array}$ & î & $\frac{a}{n}$ \\
\hline $\begin{array}{l}\text { Бурштинська } \\
\text { TЕС } \\
\text { (енергоблоки 8) }\end{array}$ & $\mathfrak{\infty}_{\infty}^{n}$ & $\begin{array}{l}\text { n. } \\
0 \\
\infty \\
\infty\end{array}$ & 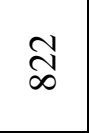 & 我 & $\stackrel{n}{n}$ & $\frac{m}{a}$ & $\stackrel{n}{N}$ & $\stackrel{\infty}{8}$ & $\begin{array}{l}0 \\
6 \\
6\end{array}$ & â & $\vec{\infty}$ & 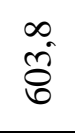 & in & $\begin{array}{l}\forall \\
n \\
n\end{array}$ & $\vec{m}$ & $\hat{\varnothing}$ \\
\hline Разом & $\frac{\infty}{6}$ & $\begin{array}{l}\infty \\
\hat{n} \\
\tilde{n}\end{array}$ & $\underset{n}{\tilde{N}}$ & $\begin{array}{l}0 \\
\dot{f} \\
n \\
n\end{array}$ & $\begin{array}{l}n \\
n \\
n \\
n\end{array}$ & $\begin{array}{l}n \\
\text { no } \\
n \\
n\end{array}$ & $\begin{array}{l}+ \\
\stackrel{+}{\sigma} \\
\stackrel{\sigma}{\sigma}\end{array}$ & 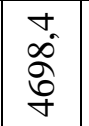 & $\begin{array}{l}m \\
\stackrel{2}{\infty} \\
\dot{y}\end{array}$ & 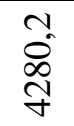 & $\frac{1}{3}$ & $\begin{array}{l}\overrightarrow{\hat{d}} \\
\infty \\
0\end{array}$ & $\begin{array}{l}\vec{n} \\
\hat{n} \\
n\end{array}$ & ষ্ & $\begin{array}{l}a \\
\dot{H} \\
\text { ñ } \\
m\end{array}$ & $\begin{array}{l}a \\
\text { ஸे } \\
\text { ồ }\end{array}$ \\
\hline \multicolumn{17}{|c|}{ Вимоги до щорічного скорочення у період 2018-2033 років обсягів викидів пилу (т/рік) } \\
\hline $\begin{array}{l}\text { Бурштинська } \\
\text { TЕС } \\
\text { (енергоблоки } \\
9,10,11,12) \\
\end{array}$ & ๙ิ่ & \begin{tabular}{l}
0 \\
\multirow{n}{*}{} \\
f
\end{tabular} & $\begin{array}{l}n \\
\text { กิ } \\
\text { of }\end{array}$ & $\underset{n}{\stackrel{+}{n}}$ & $\begin{array}{l}\stackrel{v}{i} \\
\stackrel{d}{m}\end{array}$ & 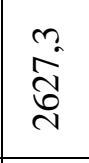 & $\begin{array}{l}\text { â } \\
\text { ñ } \\
\text { ñ }\end{array}$ & $\stackrel{5}{\hat{\sigma}}$ & ิㅗ & 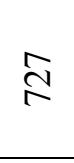 & $\frac{a}{n}$ & - & - & - & - & - \\
\hline $\begin{array}{l}\text { Бурштинська } \\
\text { TЕС } \\
\text { (енергоблоки 8) }\end{array}$ & 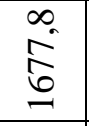 & $\begin{array}{l}\vec{n} \\
\stackrel{n}{2}\end{array}$ & $\begin{array}{l}\vec{v} \\
\text { ñ } \\
\text { ñ }\end{array}$ & ڤ્ & సิ & \begin{tabular}{l}
$\sim$ \\
\multirow{d}{*}{} \\
$\infty$
\end{tabular} & $\frac{n}{2}$ & $\begin{array}{l}\infty \\
\infty \\
\infty \\
n\end{array}$ & $\frac{7}{6}$ & $\stackrel{\vec{r}}{\vec{N}}$ & $\ddot{\tilde{n}}$ & - & - & - & - & $\begin{array}{lll}- & -\end{array}$ \\
\hline Разом & $\begin{array}{l}n \\
2 \\
\infty \\
0 \\
0\end{array}$ & î & $\begin{array}{l}9 \\
\dot{0} \\
\dot{0} \\
\text { n }\end{array}$ & $\begin{array}{l}\overrightarrow{5} \\
\frac{8}{8}\end{array}$ & $\begin{array}{l}\stackrel{+}{2} \\
\stackrel{\overbrace{}}{\forall}\end{array}$ & 吕 & $\begin{array}{l}\hat{n} \\
\hat{n} \\
\infty\end{array}$ & $\begin{array}{l}\hat{n} \\
\vec{\lambda}\end{array}$ & $\begin{array}{l}n \\
\infty \\
\infty \\
n \\
n\end{array}$ & $\stackrel{+}{\circ}$ & $\begin{array}{l}0 \\
\text { î } \\
\text { d }\end{array}$ & - & - & - & - & - \\
\hline
\end{tabular}

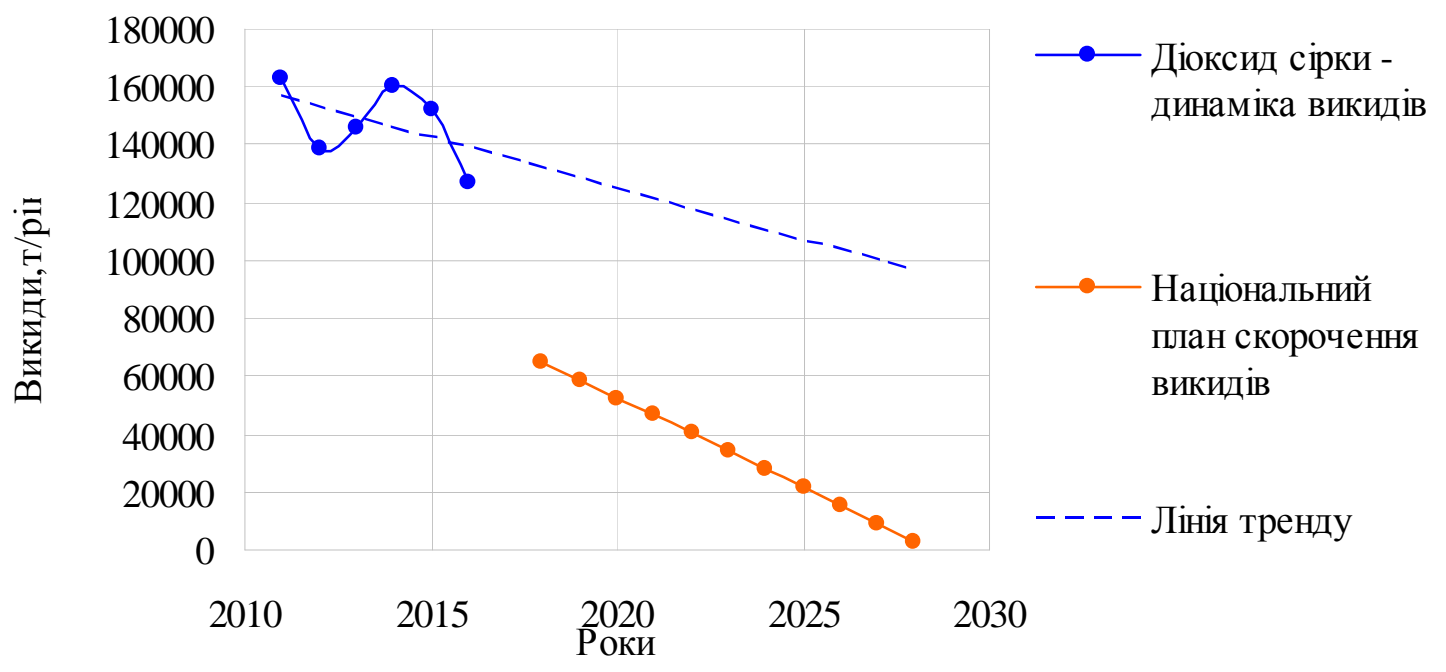

Рис. 1. Викиди діоксиду сірки - планова та прогнозна оцінка 


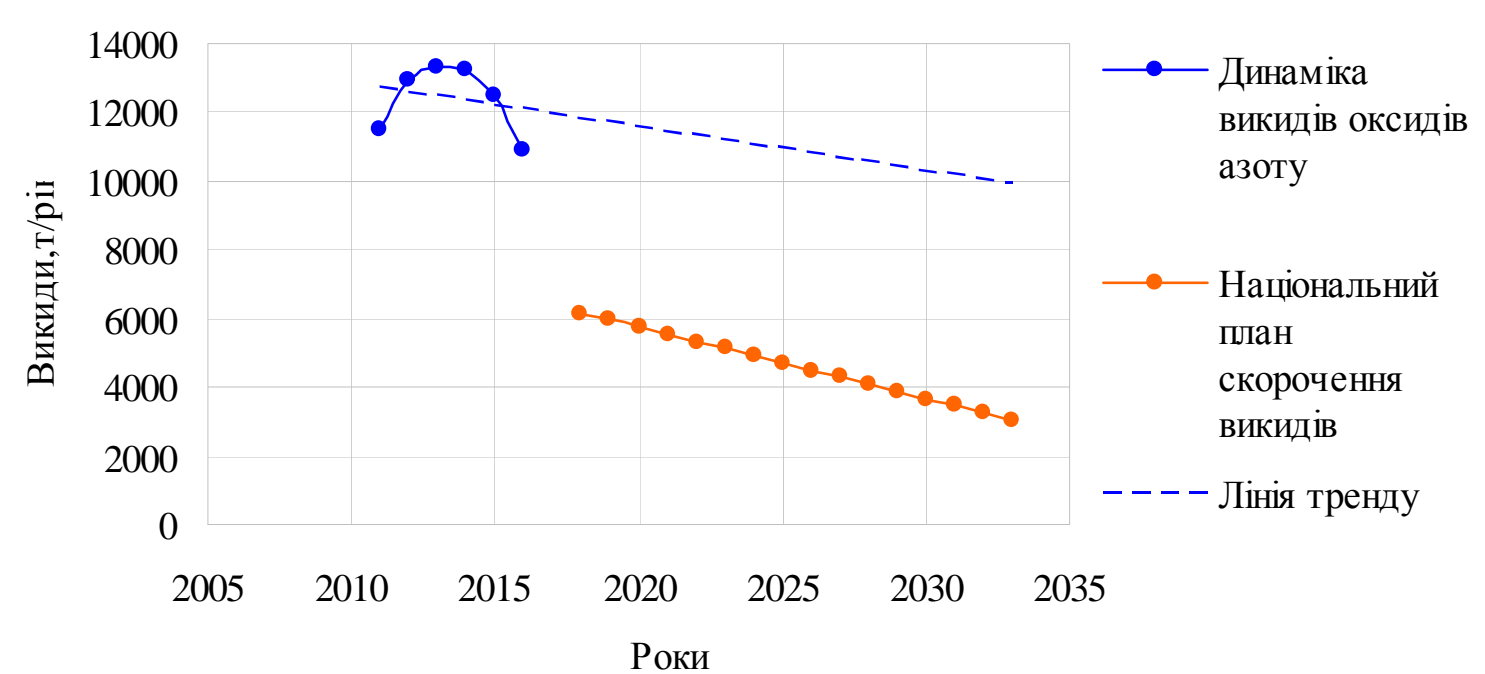

Рис. 2. Викиди оксидів азоту - планова та прогнозна оцінка

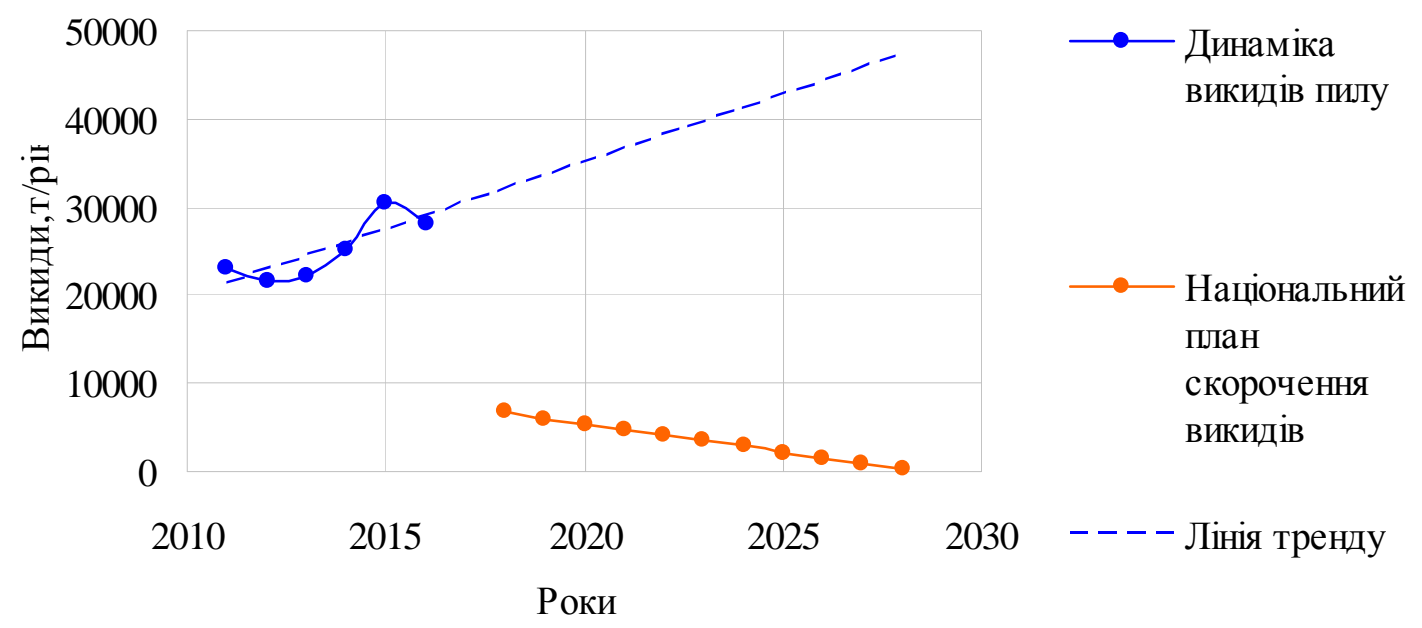

Рис. 3. Викиди речовин у вигляді суспендованих твердих частинок, недиференційованих за складом - планова та прогнозна оцінка

Клас небезпеки визначають токсичністю промислових відходів. Токсичними називають такі відходи, які утворюються в процесі технологічного циклу в промисловості і мають у своєму складі фізіологічно активні речовини, що спричиняють токсичний ефект.

Індекс токсичності розраховують з урахуванням вагових коефіцієнтів.

Індекс токсичності визначаємо за такою залежністю [9]:

$$
T I=W i \cdot q_{i},
$$

де $W$ - відносний ваговий коефіцієнт; $q_{i}$ - шкала оцінювання якості для кожного викиду.

Відносний ваговий коефіцієнт визначаємо за такою залежністю:

$$
W_{i}=w_{i} / \Sigma w_{i},
$$

де $w_{i}$ - ваговий коефіцієнт.

Шкала оцінювання якості для кожного викиду:

$$
q_{i}=C_{i С С 3} / Г Д K_{i},
$$

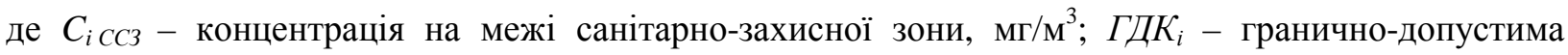
концентрація.

Результати розрахунків наведені на рис. 4 та в табл. 4.

Аналіз рисунку 4 свідчить про перевищення ГДК для деяких забруднювальних речовин. Визначивши індекс токсичності, який враховує як клас небезпеки речовини, так і ступінь перевищення ГДК, можна давати рекомендації щодо зменшення викидів певних речовин, а також щодо вибору палива з меншим їхнім вмістом. 


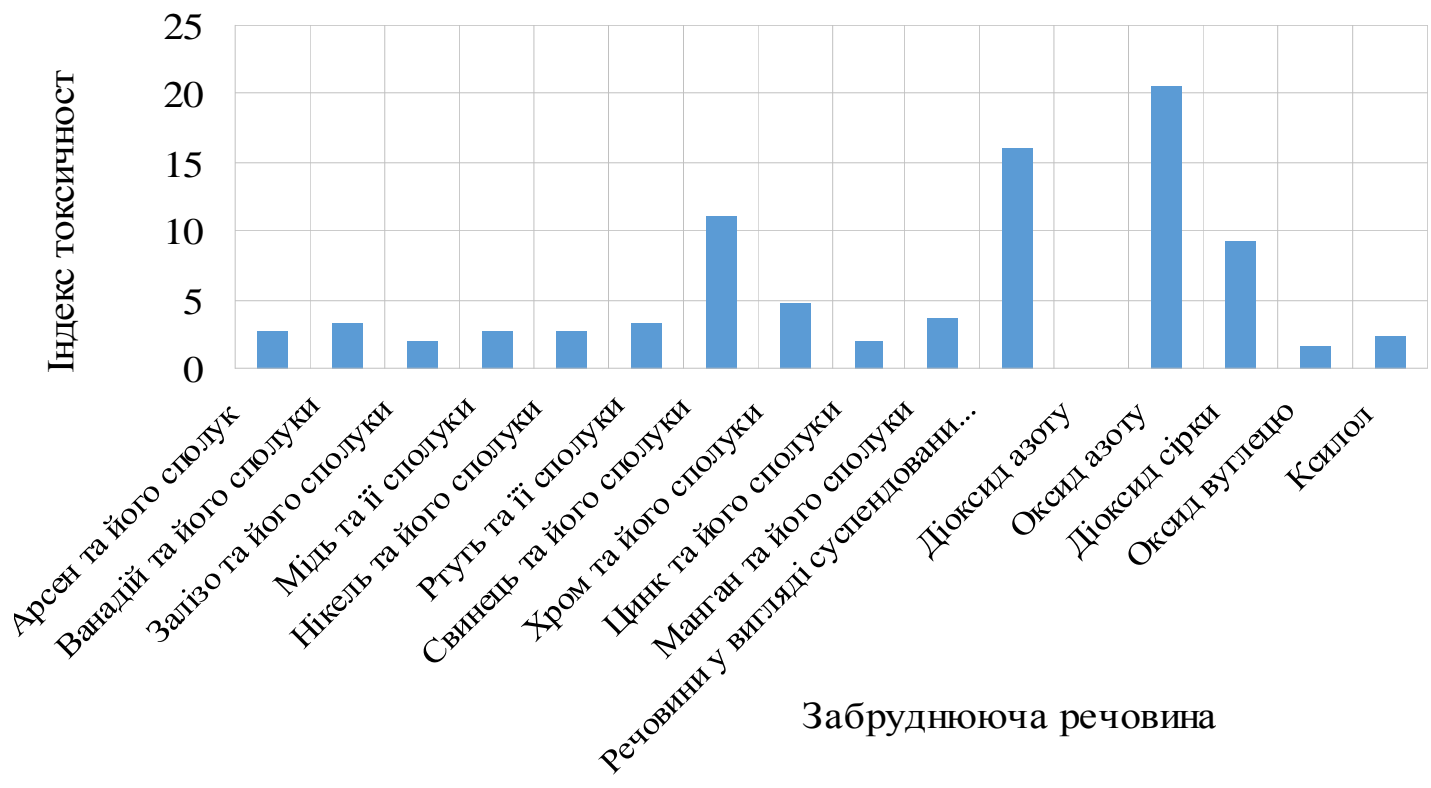

Рис. 4. Значення індексу токсичності

Розрахунок індексу токсичності

\begin{tabular}{|c|c|c|c|c|c|c|c|c|c|}
\hline $\begin{array}{l}\text { № } \\
\text { 3/ח }\end{array}$ & $\begin{array}{c}\text { Назва } \\
\text { забрудню- } \\
\text { вальної } \\
\text { речовини }\end{array}$ & $\begin{array}{c}\text { Клас } \\
\text { небезпеки }\end{array}$ & $\begin{array}{c}\text { Концентрація } \\
\text { на межі } \\
\text { санітарно- } \\
\text { захисної зони } \\
C_{i C C 3}, \text { мг/м } \\
\end{array}$ & $\begin{array}{l}\Gamma Д \kappa_{i}, \\
\mathrm{MГ} / \mathrm{M}^{3}\end{array}$ & Викиди, т & $\begin{array}{c}\text { Ваговий } \\
\text { коефіцієнт } \\
w_{i}\end{array}$ & $\mid \begin{array}{c}\text { Відносний } \\
\text { ваговий } \\
\text { коефіцієнт } \\
W_{i}\end{array}$ & $q_{i}$ & $\begin{array}{c}\text { Індекс } \\
\text { токсичності } \\
T I\end{array}$ \\
\hline 1 & $\begin{array}{l}\text { Арсен та його } \\
\text { сполук }\end{array}$ & 2 & 0,0012 & 0,003 & 4,788 & 4 & 6,6667 & 0,4 & 2,6667 \\
\hline 2 & \begin{tabular}{|l|} 
Ванадій та \\
його сполуки
\end{tabular} & 1 & 0,0008 & 0,002 & 0,018 & 5 & 8,3333 & 0,4 & 3,3333 \\
\hline 3 & $\begin{array}{l}\text { Залізо та його } \\
\text { сполуки }\end{array}$ & 3 & 0,016 & 0,04 & 0,145 & 3 & 5 & 0,4 & 2 \\
\hline 4 & \begin{tabular}{|l|} 
Мідь та іï \\
сполуки
\end{tabular} & 2 & 0,0012 & 0,003 & 3,798 & 4 & 6,6667 & 0,4 & 2,6667 \\
\hline 5 & $\begin{array}{l}\text { Нікель та його } \\
\text { сполуки }\end{array}$ & 2 & 0,0004 & 0,001 & 4,33 & 4 & 6,6667 & 0,4 & 2,6667 \\
\hline 6 & $\begin{array}{l}\text { Ртуть та її } \\
\text { сполуки }\end{array}$ & 1 & 0,00012 & 0,0003 & 0,41 & 5 & 8,3333 & 0,4 & 3,3333 \\
\hline 7 & \begin{tabular}{|l|} 
Свинець та \\
його сполуки
\end{tabular} & 1 & 0,0004 & 0,0003 & 4,564 & 5 & 8,3333 & 1,3333 & 11,1111 \\
\hline 8 & $\begin{array}{l}\text { Хром та його } \\
\text { сполуки }\end{array}$ & 1 & 0,00116 & 0,002 & 5,591 & 5 & 8,3333 & 0,58 & 4,8333 \\
\hline 9 & $\begin{array}{l}\text { Цинк та його } \\
\text { сполуки }\end{array}$ & 3 & 0,02 & 0,05 & 13,317 & 3 & 5 & 0,4 & 2 \\
\hline 10 & \begin{tabular}{|l} 
Манган та \\
його сполукки
\end{tabular} & 2 & 0,0056 & 0,01 & 0,05 & 4 & 6,6667 & 0,56 & 3,7333 \\
\hline 11 & \begin{tabular}{|l|} 
Речовини у \\
вигляді \\
суспендованих \\
твердих \\
частинок \\
\end{tabular} & 4 & 0,725 & 0,15 & 27960,271 & 2 & 3,3333 & 4,8333 & 16,1111 \\
\hline 12 & Діоксид азоту & 3 & & 0,2 & 10749,752 & 4 & 6,6667 & 0 & 0 \\
\hline 13 & Оксид азоту & 2 & 0,12325 & 0,04 & 124,818 & 4 & 6,6667 & 3,0812 & 20,5417 \\
\hline 14 & Діоксид сірки & 3 & 0,93 & 0,5 & 127097,61 & 3 & 5 & 1,86 & 9,3 \\
\hline 15 & Оксид вуглецю & 4 & 1,55 & 3,0 & 979,835 & 2 & 3,3333 & 0,5167 & 1,7222 \\
\hline 16 & Ксилол & 3 & 0,096 & 0,2 & 0,381 & 3 & 5 & 0,48 & 2,4 \\
\hline
\end{tabular}


За індексом токсичності здійснюється поділ викидів на групи (табл. 5). Згідно з табл. 5 до групи надзвичайно токсичних викидів належить оксид азоту (індекс токсичності складає 20,54).

\section{Поділ на групи залежно від індексу токсичності}

Таблиия 5

\begin{tabular}{|l|l|c|l|}
\hline \multicolumn{1}{|c|}{$T I$} & \multicolumn{1}{|c|}{$\begin{array}{c}\text { Характеристика } \\
\text { токсичності }\end{array}$} & $\begin{array}{c}\text { Кількість } \\
\text { шкідливих речовин }\end{array}$ & $\begin{array}{c}\text { Назва шкідливої речовини } \\
\text { (порядковий номер у таблиці 4) }\end{array}$ \\
\hline$<4,9$ & Малотоксичні & 12 & $1,2,3,4,5,6,8,9,10,12,15,16$ \\
\hline $5-9,9$ & Помірно токсичні & 1 & Діоксид сірки \\
\hline $10-14,9$ & Токсичні & 1 & Свинець та його сполуки \\
\hline $15-19,9$ & Дуже токсичні & 1 & $\begin{array}{l}\text { Речовини у вигляді суспендованих } \\
\text { твердих частинок }\end{array}$ \\
\hline $20-25$ & Надзвичайно токсичні & 1 & Оксид азоту \\
\hline
\end{tabular}

Оксиди азоту шкідливо впливають на здоров'я людини, сприяють утворенню парникового ефекту та руйнуванню озонового шару. Крім того, оксиди азоту викликають «вимирання лісів», кислотні дощі [13].

Речовини у вигляді суспендованих твердих частинок, індекс токсичності яких 16,11, належать до дуже токсичних викидів.

Свинець та його сполуки за індексом токсичності 11,11 згідно з таблицею 5 належать до токсичних викидів. Свинець може потрапляти в організм людини інгаляційним шляхом у вигляді аерозолей та пилу. Ступінь його поглинання через легені залежить від величини аерозольних частинок [13].

Висновки. Виконано аналіз викидів забруднювальних речовин в атмосферне повітря стаціонарними джерелами та наведено прогнозну оцінку подальших викидів, що дасть змогу провести заходи щодо їхнього мінімізування.

Рекомендовано вибір палива з меншим вмістом у викидах не лише таких речовин як оксид азоту, речовини у вигляді суспендованих твердих частинок, діоксиду сірки (що передбачено «Національним планом скорочення викидів від установок для спалювання палива»), але і свинцю та його сполук. При встановленні та реконструкції систем очищення димових газів для Бурштинської ТЕС необхідно враховувати фільтрувальну здатність обладнання щодо речовин із високим значенням індексу токсичності.

Для уніфікації розрахунків, аналізу в розрізі обраного періоду часу, можливості застосування для інших об'єктів господарювання було розроблено програмне забезпечення. Всі дані для обробки спочатку заносять до бази даних, а потім шляхом виконання запиту подають на обробку, згодом дані зберігають і на основі вже розрахованих даних будують вибіркові таблиці та графіки.

Подальший напрям досліджень полягає у розробленні багатофункціональної системи техногенно-екологічної безпеки об’ єктів паливно-енергетичного комплексу.

\section{Література}

1 Адаменко О. М., Рудько Г. І., Консевич Л. М. Екологічне картування. Івано-Франківськ : IME, 2003. $580 \mathrm{c}$.

2 Адаменко Я. О., Консевич. Л. М. Оцінка впливів на навколишнє середовище. ІваноФранківськ : ІФНТУНГ, 2002. 48 с.

3 Білецька Г. А. Моніторинг довкілля. Львів : 2013. 149 с.

4 ДСП 173-96. Державні санітарні правила планування та забудови населених пунктів, затверджені наказом Міністерства охорони здоров'я України від 19 червня 1996 р. № 173.

5 Енергоекологічна безпека нафтогазових об'єктів : монографія / Р. М. Говдяк та ін. ІваноФранківськ : Лілея-НВ, 2007. 556 с.

6 Клименко М. О., Залеський. І. І. Техноекологія. Рівне, 2010. 298 с.

7 Kryvenko G. M., Vozniak L. V. Research of pollutants emissions into the atmosphere by stationary sources // Book of abstracts III International Scientific-Technical Conference. Kielce. 2019. P.58.

8 Крижанівський Є. І., К Кошлак Г. В. Екологічні проблеми енергетики // Нафтогазова енергетика. 2016. № 1(25) С. 80-90. 
9 Md. Khorshed Ali, Atik Sarraz, Preetom Kishore Roy, Roky Mallick, Sagar Das. Assesment of Toxicity Index of Different Heavy Metals from Industrial Discharge // Journal of Environmental Science, Toxicology and Food Technology. Vol.10, 2016. P 43-46.

10 Медников Е. П. Турбулентный перенос и осаждение аэрозолей. М. : Наука, 1981. 176 с.

11 Панківський Ю. І., Ошуркевич-Панківська О. Є., Осташук М. Б. Оцінювання впливу Бурштинської ТЕС на атмосферне повітря // Науковий вісник НЛТУ України. 2017. Т. 27, № 5. C. 59-62.

12 Перспективи роботи TEC в умовах сучасних екологічних вимог. 16 с. URL: https://dtek.com/content/files/iryna-verbitska.pdf .

13 Плачкова С. Г. Энергетика. История, настоящее и будущее: книга 5. Электроэнергетика и охрана окружающей среды. Функционирование энергетики в современном мире. 2005. URL: http://energetika.in.ua/ru/books/book-5.

14 Про Національний план скорочення викидів від установок для спалювання палива: розпорядження Кабінету Міністрів України. 2017. № 796-p. URL: http://mpe.kmu.gov/ua.

15 Регіональна доповідь про стан навколишнього середовища в Івано-Франківській області в 2016 році. Івано-Франківськ, 2017. 188 с. URL: htths://menr.gov.ua/files/docs/Reg.report.

\section{G. Kryvenko, L. Vozniak, V. Zorin \\ Ivano-Frankivsk National Technical University of Oil and Gas}

\section{ANALYSIS OF POLLUTANTS EMISSION INTO THE ATMOSPHERE BY STATIONARY SOURCES}

The emission of harmful substances into the air has been studied for Ivano-Frankivsk oblast, as it has a considerable number of recreational resources.

Wastes from electricity production at thermal power plants worsen the environmental situation in the country. Solving the problems associated with environmental protection and improving the quality of its social component is always a topical issue. It is important to reduce the man-made impact on the environment by heat generating companies.

The purpose of the article is to analyze and forecast the emissions of pollutants into the air by stationary sources. In the process of research, the authors have solved the issues of analysis of ground level concentration of pollutants at the border of the sanitary protection zone and the forecast estimation of future emissions.

The change in emissions of pollutants for a certain period of time has been analyzed. The ground level concentrations of pollutants at the border of the sanitary-protective zone have been calculated to analyze the existing emissions of Burshtynska thermal power plant (TPP) and compare them with the maximum allowable concentrations (MAC). Burshtynska TPP is in the category 2 hazard. The authors have performed the forecast estimation of future emissions and proposed the measures to minimize them. The toxicity index has been calculated taking into account weight coefficients. The analysis of emissions indicates excessive MAC for some pollutants. According to the toxicity index, which takes into account both the substance hazard category and the degree of excessive MPC, the authors have proposed the measures for reducing the emissions of certain substances and using the fuel with their lower content.

It is recommended to choose the fuel with the lower content in emissions not only of such substances as nitrogen oxide, suspended solids, sulfur dioxide, but also lead and its compounds. When installing and reconstructing the flue gas cleaning systems for Burshtynska TPP, it is necessary to take into account the equipment filterability for the substances with high toxicity index.

The authors have developed the software to unify the calculations, perform analysis for a certain time period, and check the applicability for other business entities.

Keywords: forecast estimation, sulfur dioxide, nitrogen oxide, concentration, toxicity index.

\section{References}

1 Adamenko O. M., Rudko G. I., Konsevych L. M. Ekologichne kartuvannia. Ivano-Frankivsk: IME, 2003. $580 \mathrm{~s}$.

2 Adamenko Ya. O., Konsevych L. M. Otsinka vplyviv na navkolyshnie seredovyshche. IvanoFrankivsk: IFNTUNG, 2002. $48 \mathrm{~s}$. 
3 Biletska G. A. Monitoryng dovkillia. Lviv: 2013. 149 s.

4 DSP 173-96. Derzhavni sanitarni pravyla planuvannia ta zabudovy naselenykh punktiv, zatverdzheni nakazom Ministerstva okhorony zdorovia Ukrainy vid 19 chervnia 1996 r., \# 173.

5 Energoekologichna bezpeka naftogazovykh obiektiv: monografiia / R. M. Govdiak, ta in. IvanoFrankivsk: Lileia, NV, 2007. $556 \mathrm{s.}$

6 Klymenko M. O., Zaleskyi I .I Tekhnoekologiia. Rivne: 2010298 s.

7 Kryvenko G. M., Vozniak L. V. Research of pollutants emissions into the atmosphere by stationary sources // Book of abstracts III International Scientific-Technical Conference. Kielce, 2019. P.58.

8 Kryzhanivskyi Ye. I., Koshlak G. V. Ekologichni problemy energetyky // Naftogazova energetyka. 2016. \# 1 (25) S.80 - 90.

9 Md. Khorshed Ali, Atik Sarraz, Preetom Kishore Roy, Roky Mallick, Sagar Das. Assesment of Toxicity Index of Different Heavy Metals from Industrial Discharge // Journal of Environmental Science, Toxicology and Food Technology. Vol.10, 2016.P 43 - 46.

10 Mednikov Ye. P. Turbulientnyi pierienos i osazhdieniie aerozoliei. Moscow: Nauka, 1981. $176 \mathrm{~s}$.

11 Pankivskyi Yu. I., Oshurkevych-Pankivska O. Ye., Ostashuk M. B. Otsinniuvannia vplyvu Burshtynskoi TES na atmosferne povitria // Naukovyi visnyk NLTU Ukrainy, 2017, 27, \# 5 S.59 - 62.

12 Perspektyvy roboty TES v umovakh suchasnykh ekologichnykh umov. 2018. - 16 s. URL: [https://dtek.com/content/files/iryna-verbitska.pdf.

13 Plachkova S. G. Energetika. Istoriia, nastoiashcheie I budushcheie: kniga 5. Eliektroenergetika i okhrana okruzhaiashchei sriedy. Funktsionirovaniie energetiki v sovriemiennom mirie. 2005. URL: http://energetika.in.ua/ru/books/book-5.

14 Pro Natsionalnyi plan skorochennia vykydiv vid ustanovok dlia spaliuvannia palyva: rozporiadzhennia Kabinetu Ministriv Ukrainy. 2017. \# 796-r. URL: http://mpe.kmu.gov/ua.

15 Regionalna dopovid pro stan navkolyshnogo seredovyshcha v Ivano-Frankivskii oblasti v 2016 rotsi. Ivano-Frankivsk, 2017. 188 s. URL: htths://menr.gov.ua/files/docs/Reg.report.

Надійшла до редакиї 5 травня 2019 р. 